\title{
PERFORMANCE EVALUATION OF SOLID-SET SPRINKLER IRRIGATION UNDER DIFFERENT PRESSURES AND NOZZLE DIAMETERS
}

\author{
Adel H. Elmetwalli ${ }^{1}$, A. Derbala ${ }^{1}$ and Waleed Darwisch ${ }^{2}$
}

\begin{abstract}
Low irrigation efficiency and limited fresh water resources become serious issues worldwide particularly in arid and semi-arid regions. Rapidly deep percolation of water especially in light-textured soils needs efficient irrigation systems for water application. The overall irrigation efficiency can be increased through choosing the optimum operating conditions. This study investigated the effects of both operating pressure and nozzle diameter on the performance of the solid set sprinkler irrigation system. Three levels of operating pressure of (160, 180 and $200 \mathrm{kPa}$ ) and three different nozzle diameter of 3.0, 4.2, and $5.2 \mathrm{~mm}$ were used. The distribution efficiency of water was evaluated through the calculation of Christiansen's uniformity coefficient (CU), distribution uniformity, application uniformity and precipitation rate. The results demonstrated that $180 \mathrm{kPa}$ operating pressure produced the highest distribution uniformity, coefficient of uniformity and application uniformity.
\end{abstract}

Keywords: solid set, sprinkler, irrigation, distribution, application, uniformity, pressure, nozzle

\section{INTRODUCTION}

Trigation process is considered one of the main factors affecting agricultural production. In case of limited water resources like in

Egypt, it is crucial to choose the optimum irrigation system to add the required amount of water to grow crops in an efficient way (Dukes and Perry, 2006).

1)Assi., and Assoc., Prof., respect., Agric. Eng. Dept., Fac., of Agric., Tanta Univ., Egypt.

2)Assi., Prof., Agric. Eng., at Environmental Study and Research Institute, Sadat City Univ., Egypt. 
Water is a natural resource of vital importance and thus efficient systems are extremely needed to apply water to crops (Armindo et al., 2011). On farm irrigation systems are usually designed aiming to achieve optimum performance at a specific upstream pressure head (Daccache $\boldsymbol{e t}$ al., 2010). The effectiveness of sprinkler irrigation to apply water in a highly uniform pattern and thus efficient distribution throughout irrigated areas is considered a major limiting factor to crop growth and yield (Smajstrla et al., 1990). Sprinkler irrigation mainly depends on hydraulic and environmental conditions. The uniformity of the water distribution also depends on the layout of sprinklers, operating pressure, spacing between sprinklers, climatic condition particularly wind speed and nozzle diameter (Tarjuelo et al., 1999; Loule and Selker, 2000; Playan et al., 2006). Playan et al., 2005 concluded that wind speed is the most affecting climatic parameter on sprinkler irrigation distribution uniformity of water which increases evaporation losses and wind drift. The nozzle diameter is considered one of the main parameters affecting the performance of sprinkler irrigation systems (Kara et al., 2008). The nozzle performance controls the efficiency of the whole system since it controls the droplet size and thus increases or decreases the droplets drift (Wilson and Zoldoske, 1997). The main function of sprinkler nozzles is to distribute water in a uniform pattern without having any surface flow or excessive drainage from the root zone (Kara et al., 2008). Wetted diameter and precipitation profile are greatly dependant on both nozzle diameter and sprinkler type (Daccache et al., 2010).

Operating pressure is also considered one of the main factors affecting the performance of sprinkler irrigation systems. Previous studies investigated the effects of operating pressure on the efficiency of water distribution in sprinkler irrigation systems. For example, Amer (2006) pointed out that high water distribution uniformity can be achieved when choosing optimal operating pressure, height, trajectory angle and sprinkler layout. He also mentioned that it can be also achieved through decreasing the loss of pressure occurs in lateral lines and this loss should not exceed 10\%. El-Sayed (2009) compared the performance of two floppy sprinklers (original and local types) under various operating pressure and riser height levels. They found that the optimum operating 
pressure and riser height to achieve maximum distribution uniformity was $200 \mathrm{kPa}$ and $2 \mathrm{~m}$, respectively.

The overall aim of this research was to investigate the performance of a solid-set sprinkler system under different operating pressures and nozzle diameters.

\section{MATERIALS AND METHODS}

The experimental work of this study was undertaken at the farm of Environmental Study and Research Institute, Sadat City University, Mynofia Province. To evaluate the performance of the solid-set sprinklers under different operating pressures and nozzle diameters. Care was taken to avoid windy days which affect the pattern of water distribution. Sprinklers were arranged in a rectangle layout of $12 \times 16 \mathrm{~m}$ with a riser height of $1.2 \mathrm{~m} .15 \mathrm{~cm}$ diameter and $10 \mathrm{~cm}$ height plastic catch cans were used to collect water under sprinklers which were distributed according to (ASAE standard, 2001). Sprinkler discharge rate was determined using a flexible hose which was connected directly to the sprinkler nozzle. A 20 litre container was used to collect water for five minutes and the discharge rate was calculated according to Melvyn, 1983 as follows:

$$
\mathrm{Q}=\mathrm{v} / \mathrm{t}
$$

Where:

$\mathrm{Q}=$ the discharge rate in $\mathrm{L} / \mathrm{min}$,

$\mathrm{t}=$ the time in $\min$ and

$\mathrm{v}=$ the volume of collected water in $\mathrm{L}$.

The operating pressure was controlled using a pressure regulator and measured by a pressure gage. The pressure was adjusted at three levels of 160,180 , and $200 \mathrm{kPa}$ and three different nozzle diameters of 3, 4.2 and $5 \mathrm{~mm}$ were also used to evaluate the performance of sprinklers.

\section{Precipitation rate}

Following the calculation of discharge rate, the precipitation rate was calculated using the following equation (Melvyn, 1983):

$$
\mathrm{I}=\frac{Q}{A}
$$


Where I is the precipitation rate in $\mathrm{mm} / \mathrm{hr}, \mathrm{Q}$ is the discharge rate in $\mathrm{L} / \mathrm{hr}$ and $\mathrm{A}$ is the area served by each sprinkler in $\mathrm{m}^{2}$

\section{Distribution uniformity}

Distribution uniformity is one of the most commonly used indicators for evaluating sprinkler irrigation and was calculated according to Heerman et al., 1990 as follows.

$$
\mathrm{DU}=100\left(\mathrm{Z}_{\mathrm{lq}} / \mathrm{Z}_{\mathrm{av}}\right)
$$

Where DU is the distribution uniformity in \%

$Z_{\mathrm{lq}}$ is the mean depth in catch cans of the low quarter in $\mathrm{mm}$

$\mathrm{Z}_{\mathrm{av}}$ is the mean depth in all catch cans in $\mathrm{mm}$

\section{Christiansen's coefficient of uniformity}

The amounts of water caught in catch cans were also used to calculate the Christiansen's coefficient of uniformity as follows:

$$
\mathrm{CCU}=100\left[1-\frac{\Sigma\left|x_{i}-x^{\prime}\right|}{n x^{\prime}}\right]
$$

Where, CCU is the Christiansen's coefficient of uniformity in \%

$x_{i}$ is the water amount caught at a specific point in $\mathrm{mm}$

$x^{\prime}$ is the mean of all amounts caught in catch cans in $\mathrm{mm}$

$n$ is the number of catch cans used

\section{Application Efficiency of low quarter}

Application efficiency of low quarter was calculated according Merriam and Keller, 1978 as follows:

$$
\mathrm{AELQ}=\frac{Z_{r, l q}}{d}
$$

Where:

$Z_{r, l q}$ is the average of low quarter depth collected in catch cans in $\mathrm{mm}$ $d$ is the mean depth of applied water in $\mathrm{mm}$

\section{RESULTS AND DISCUSSION}

\section{Association between operating pressure and discharge rate}

Prior collecting water in catch cans, the operating pressure was adjusted using a manometer and the discharge rate was calculated by the amount of water collected in a specific time period. The relationship between operating pressure and discharge rate is detailed in Table 1. Data 
obviously demonstrated that discharge rate increased with increasing operating pressure reaching a maximum of $1.36 \mathrm{~m}^{3} / \mathrm{h}$ at $200 \mathrm{kPa}$. This trend occurred at all nozzle diameter levels. The results further showed that increasing operating pressure from 160 to $200 \mathrm{kPa}$ increased discharge rate by 19,16 , and $17 \%$ at $3,4.2$ and 5.2 nozzle diameter, respectively. Broadly, it is noted that the highest discharge rate was recorded with the highest values of both pressure and nozzle diameter.

Table 1: Mean discharge rate $\left(\mathrm{m}^{3} / \mathrm{h}\right)$ of sprinklers at various operating pressure and nozzle diameter levels

\begin{tabular}{|c|c|c|c|}
\hline \multirow{2}{*}{$\begin{array}{c}\text { Nozzle diameter } \\
(\mathrm{mm})\end{array}$} & \multicolumn{3}{|c|}{ Operating pressure $(\mathrm{kPa})$} \\
\cline { 2 - 4 } & 160 & 180 & 200 \\
\hline 3 & 0.48 & 0.53 & 0.57 \\
\hline 4.2 & 0.93 & 1.01 & 1.1 \\
\hline 5.2 & 1.16 & 1.35 & 1.36 \\
\hline
\end{tabular}

\section{Effect of operating pressure and nozzle diameter on distribution uniformity}

Data illustrated in Figure 1 shows the effect of operating pressure and nozzle diameter on distribution uniformity (DU). The results showed that $180 \mathrm{kPa}$ produced the highest DU (65 and 76\% respectively) with 3 and $5.2 \mathrm{~mm}$ nozzle diameter whilst $4.2 \mathrm{~mm}$ nozzle diameter produced the highest DU at $200 \mathrm{kPa}$ operating pressure. It is noticed that increasing operating pressure over $180 \mathrm{kPa}$ decreases water distribution uniformity. Therefore it is recommended not to operate these sprinklers at an operating pressure over $200 \mathrm{kPa}$ to achieve higher DU. Low water distribution uniformity at 160 and $200 \mathrm{kPa}$ can be attributed to larger and smaller water droplets which led to non-uniform water pattern.

\section{Effect of operating pressure and nozzle diameter on application uniformity}

Figure 2 illustrates the effect of both operating pressure and nozzle diameter on application uniformity. At all nozzle diameters, operating pressure positively affected application uniformity. The results 
demonstrated that $180 \mathrm{kPa}$ operating pressure produced the highest application uniformity at all nozzle diameters. This may have been a result of small droplets which can be affected by temperature and wind drift. Increasing operating pressure from $160 \mathrm{kPa}$ to $180 \mathrm{kPa}$ increased application uniformity by $4.1,7.4$ and $31.2 \%$ at respective nozzle diameters of 3, 4.2 and $5.2 \mathrm{~mm}$. increasing operating pressure over 180 $\mathrm{kPa}$ produced less application efficiency which may have been a result of small droplets.

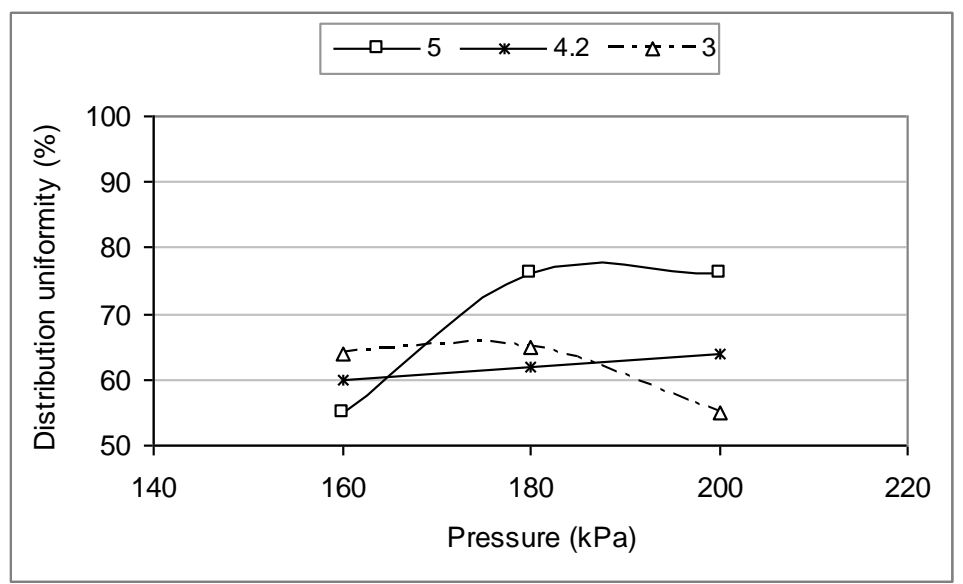

Fig. 1: Effect of operating pressure on distribution uniformity of a solidset sprinkler irrigation system at different nozzle diameters

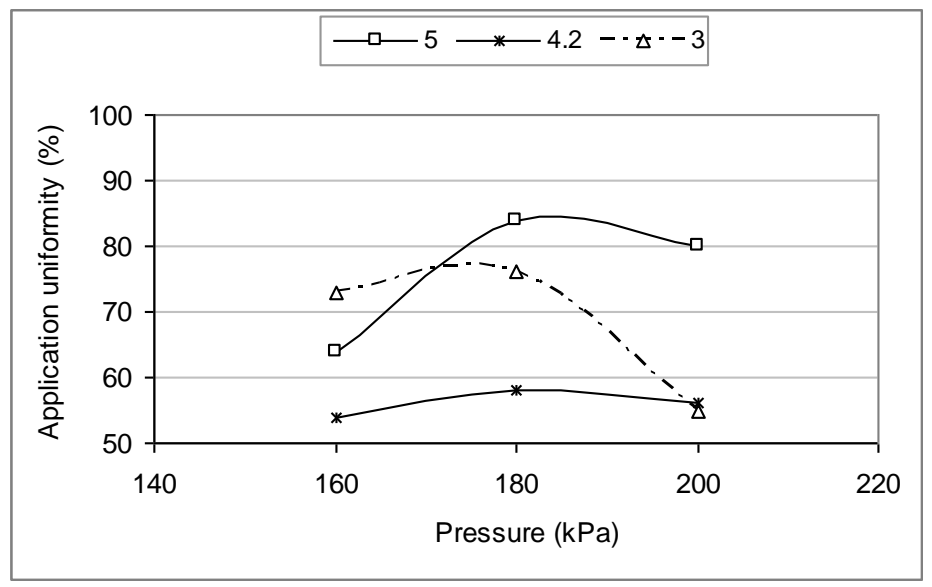

Fig. 2: Effect of operating pressure on application uniformity of a solidset sprinkler irrigation system at different nozzle diameters 


\section{Effect of operating pressure and nozzle diameter on Christiansen's coefficient of uniformity (CCU)}

Figure 3 depicted the effect of operating pressure and nozzle diameter on CCU. It is obvious that $180 \mathrm{kPa}$ produced higher CCU in comparison to 160 and $200 \mathrm{kPa}$ especially with $5 \mathrm{~mm}$ nozzle diameter. This may have been a result of medium size droplets which can give better water distribution. Increasing operating pressure from 160 to $200 \mathrm{kPa}$ with $3 \mathrm{~mm}$ nozzle diameter decreased CCU by $21 \%$. Generally, at a specific operating pressure the coefficient of uniformity increased with increasing nozzle diameter except at low operating pressures. As shown from the results, low and high operating pressures decreased CCU. This can be interpreted by larger and smaller droplets at low and high operating pressure. In case of low operating pressure, water jet does not split into smaller droplets and needs higher pressure to split and thus these droplets fall nearby sprinkles that led to non-uniform water distribution. In contrary, higher pressure forces water jet to break up into small droplets which can be lost easily as a result of evaporation or wind drift.

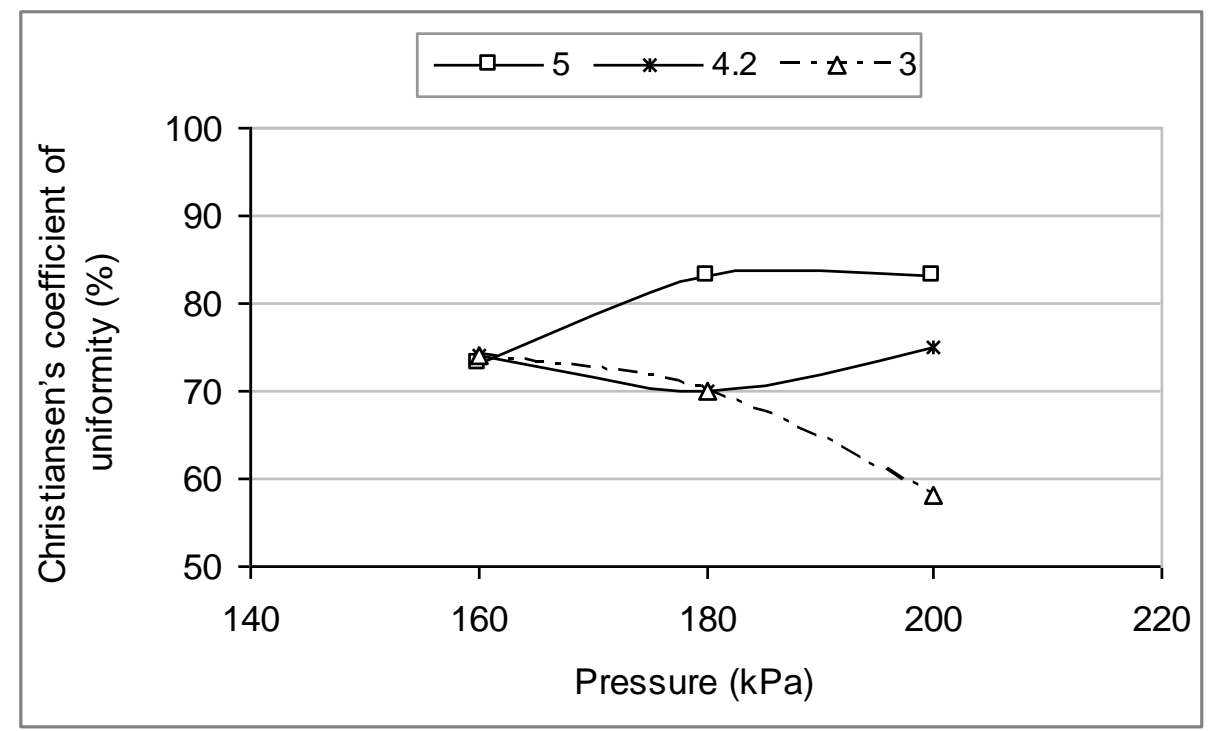

Fig. 3: Effect of operating pressure on Christiansen's coefficient of uniformity at different nozzle diameters 


\section{Precipitation rate as affected by operating pressure and nozzle diameter}

As depicted in Figure 4 it is clear that operating pressure and nozzle diameter greatly affected the precipitation rate. $200 \mathrm{kPa}$ operating pressure and $5.2 \mathrm{~mm}$ nozzle diameter achieved the highest precipitation rate of $7.1 \mathrm{~mm} \cdot \mathrm{h}^{-1}$. When operating pressure increased from 160 to 200 $\mathrm{kPa}$ the precipitation rate increased by 20,14 and $16 \%$ with $3,4.2$ and $5.2 \mathrm{~mm}$ nozzle diameter, respectively. It is obvious from the obtained results that higher precipitation rate can be accomplished by the combination of high operating pressure and greater nozzle diameter.

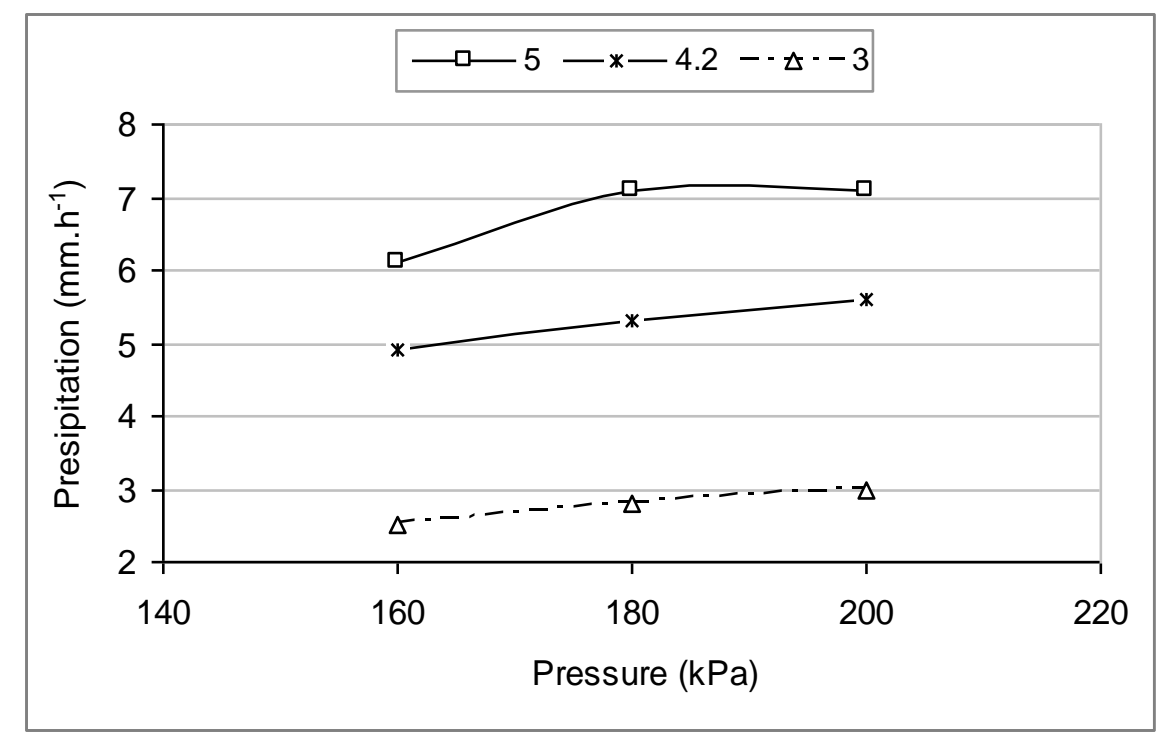

Fig. 4: Effect of operating pressure on precipitation rate of sprinklers at different nozzle diameters

\section{CONCLUSION}

In this research, solid-set sprinkler irrigation system was evaluated under different operating pressure and nozzle diameter levels. The research based on the hypothesis that high water distribution uniformity can be achieved by choosing the proper operating conditions. It can be concluded that increasing operating pressure from 160 to $200 \mathrm{kPa}$ increased discharge rate at all nozzle diameters. Coefficient of 
uniformity, application and distribution uniformity were recorded at $180 \mathrm{kPa}$ in comparison to higher and lower operating pressures. Precipitation increased with increasing both operating pressure and nozzle diameter. The results fundamentally showed that optimum operating conditions can achieve higher water distribution uniformity. Other operating parameters should be considered including riser height, sprinkles layout, and overlapping when designing sprinkler irrigation systems.

\section{REFERENCES}

Amer, K. H., 2006, Water distribution uniformity as affected by sprinkler performance. Misr J. of Agric. Eng., 23(1): 82-95.

Armindo, R. A.; Botrel, T. A. and Garzella, T. A., 2011, Flow rate sprinkler development for site-specific irrigation. Irri Sci., 29: 233240.

Daccache, A.; Lamaddalena, N. and Fratino, U., 2010, On-demand pressurized water distribution system impacts on sprinkler network design and performance. Irrigation science, 28: 331-339.

Dukes, M. D. and Perry, C., 2006, Uniformity testing of variable-rate center pivot irrigation control system. Preci Agric. 7: 205-218.

Elsayed, A. S.; M. M. Hegazi; I. H. El-Sheikh and A. F. Khader, 2009, Performance evaluation of floppy sprinklers. Misr J. Of Agric. Eng., 26(2): 766-782.

Heermann, D. F.; W. W. Wallender and G. M. Bos, 1990, Irrigation efficiency and uniformity. Management of Farm Irrigation Systems. ASAE, St. Joseph, MI. 125-149.

Kara, T.; Ekmekci, E. and Apan, M., 2008, Determining the uniformity coefficient and water distribution characteristics of 
some sprinklers. Pakistan Journal of Biological Sciences, 11(2): 214-219.

Loule, M. J. and Selker, S., 2000, Sprinkler head maintenance effects on water application uniformity. Journal of irrigation and Drainage Engineering, May-June.

Melvyn, K., 1983, Sprinkler irrigation, equipment and practice. Batsford Academic and Educational, London pp.120.

Merriam, J. L. and Keller, J., 1978, Farm irrigation system evaluation. A guide for management. Logan, Utah: Agricultural and Irrigation Engineering Department, Utah State University, USA.

Playan, E.; Salvador, R.; Faci, J. M.; Zapata, N.; Martinez-Cob, A. and Sanchez, I., 2005, Day and night wind drift and evaporation losses in sprinkler solid-sets and moving laterals. Agricultural water management, 76 (3): 139-159.

Playan, E.; Zapata, N.; Faci, J.M.; Tolosa, D. Lacueva, J. L.; Pelegrin, J.; Salvador, R.; Sanchez, I. and Lafita, A., 2006, Assessing sprinkler irrigation uniformity using a ballistic simulation model. Agricultural water management, 84: 86-100.

Smajstrla, A.G.; Boman, B.J.; Clark, G.A.; Haman, D.Z.; Zazueta, F. S., 1990, Field evaluation of irrigation systems: solid set or portable sprinkler systems. IFAS Ext. Bul. 226, University of Florida, Gainesville, FL.

Tarjuelo, J. M.; J. Montero; F. T. Honrubia; J. J. Ortiz and J. F. Ortega, 1999, Analysis of uniformity of sprinkler irrigation in a semi arid area. Agricultural water management, USA, 40: 315-331.

Wilson, T. P. and D. F. Zoldoske, 1997, Evaluating sprinkler irrigation uniformity. http://www.wateright.org/site/publications/970703.html. 


\section{الملخص العربيى}

\section{تقييم اداء نظام الرى بالرش الثابت تحت ضغوط تشغيل واقطار فوهات مختلفة}

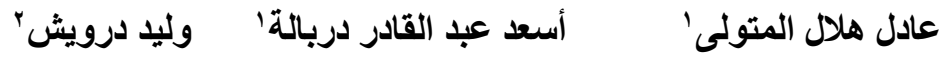

ان انخفاض كفاءة الري ومحدودية موارد المياه العذبة أصبح من القضايا المهمة في جميع أنحاء

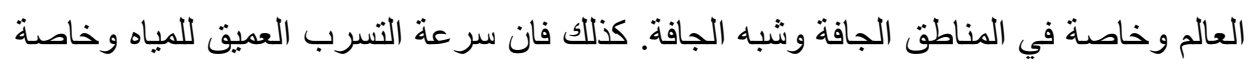

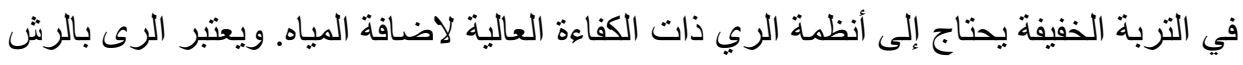

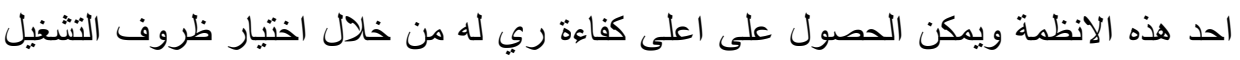
المثلى من حيث ضغوط تشغيل و اقطار الفوهات. لذلك أجريت هذه الدر اسة بمزر عة معهد الدراسات البيئية والبحوث التابع لجامعة المنوفية بمدينة

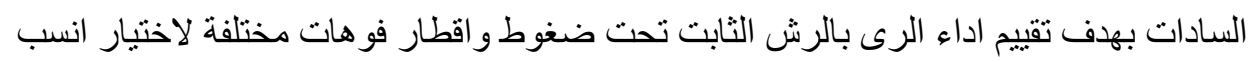
ظروف تشغيل لنظام الرى للحصول على اعلى كفاءة لتوزيع المياه.

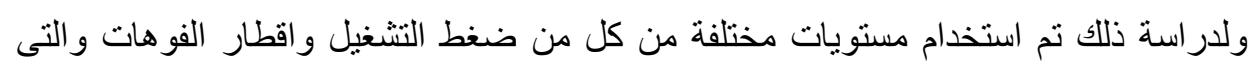
كانت كالتالى:

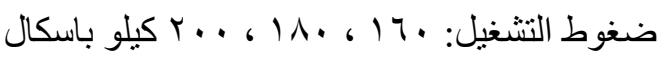

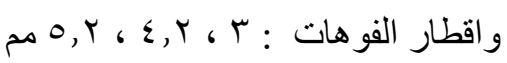

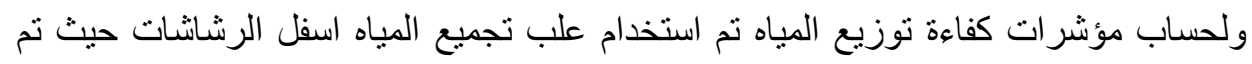

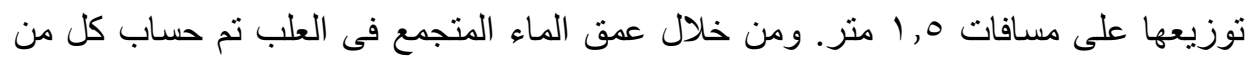

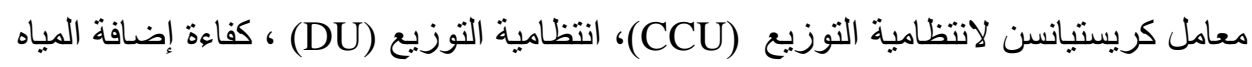
وكذلك معدل سقوط المياه(I).

وكانت أهم النتائج المتحصل عليها كالتالى: (1) أظهرت النتائج أن ضغط التشغيل • 11 أكيلو باسكال وقطر فوهة 5.2 مم حققا أعلى النتائج فى معامل كريستيانسن لانتظامية التوزيع (CU)، انتظامية التوزيع و كفاءة إضافة المياه وكنلك معدل تساقط المياه.

(1) مدرس وأستاذ مساعد الهندسة الزراعية علي التوالي ـ قسم الهندة الزراعية ـ كلية الزراعة ـ-

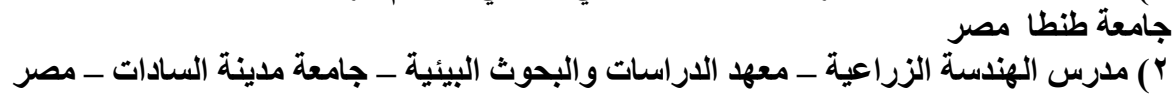




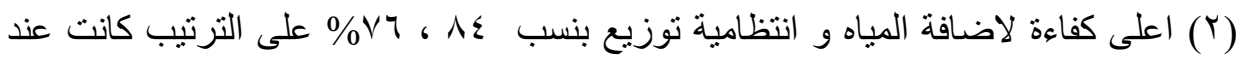
ضغط تشغيل • 11 ا كيلو باسكال وقطر فونية 5.2 مم

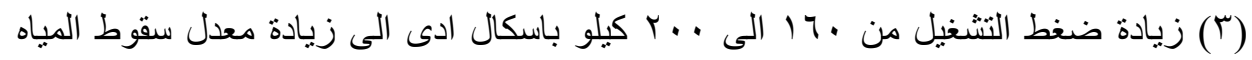

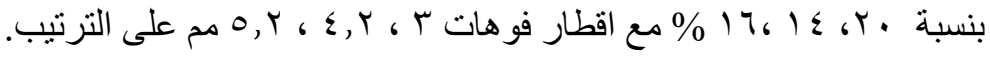

وخلصت الدراسة الى ان اختيار ضغط التشغيل المناسب مع قطر الفوهة المناسبة للرشاش يعطى اعلى مؤشرات كفاءة لنظام الرى بالرش الثابت وهى معامل كريستيانسن لانتظامية التوزيع (CCU)، انتظامية التوزيع ، كفاءة إضافة المياه وكذلك معدل سقوط المياه. ولتعميم النتائج المتحصل عليها من هذه الدراسة لابد ان نشتمل الدراسة على عو امل تصميمية اخرى مثل ارتفاع حامل الرشاشـات ، مقدار التداخل ، نظام توزيع الرشاشات (مربع - منثلث). 